\title{
65th Annual SRM Meeting, February 2012, Spokane, Washington
}

\section{By John Buckhouse}

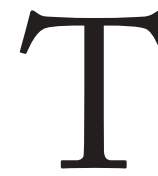

he Pacific Northwest and Idaho Sections are cohosting the 2012 meeting in Spokane, Washington. The Society for Range Management

These sections are made up of the states of Idaho, Washington, Oregon, Alaska, and the Canadian province of British Columbia. The members represented in this huge area are top-drawer-well known for their work ethic, professional acumen, dedication, and fun-loving natures. Plan to arrive early and to stay late!

You will find a wide and wonderful set of natural and cultural sites to explore and visit. Follow the path of the famous US explorers, Lewis and Clark, or the rugged Canadian explorer, McKenzie; slip over to the Pacific Coast and see the rugged landscapes carved by an ocean which is anything but "pacific"; or visit some of the West Coast's cosmopolitan cities of Portland, Seattle, Vancouver, or Victoria; taste wine in Idaho's Columbia Plateau, Washington and British Columbia's Okanagan (WA)/Okanogon (BC) valleys, or Oregon and Washington's beautiful inland valleys; visit Native American/First Nation reservations, national forests, British Columbia Crown Land, or Bureau of Land Management (BLM) desert and mountain rangelands. This is the region where the man who is often called the "Father of Range Management," Arthur D. Sampson, conducted his research. This is a land of high mountains, forests, woodlands, prairies, deserts, wide-open spaces, history, interesting

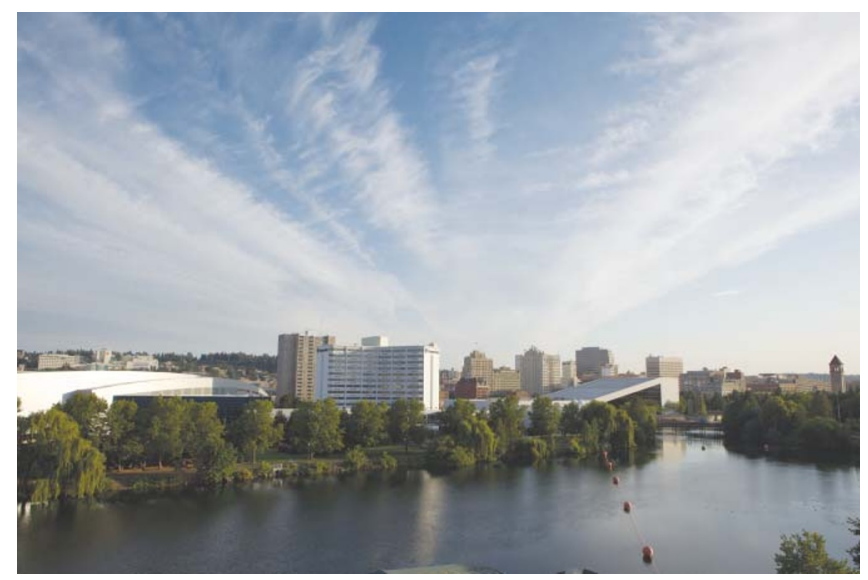

The Spokane Convention Center Campus rests alongside the Spokane River in the heart of downtown Spokane. Photo courtesy of the Spokane Regional Convention \& Visitors Bureau.

people, productive farms and rangelands, vibrant cities and strong communities. It is beautiful and varied!

Those who live here love this region and are pleased to have the opportunity to share it with you and your families!

Author is former president of the Society for Range Management and of the Pacific Northwest Section, john.c.buckhouse@oregonstate. edu. 